\title{
DOSAGE COMPENSATION OF THE SEX-LINKED ENZYME PHOSPHOGLUCOMUTASE IN THE ORTHOPTERA
}

\author{
DARCY R. HEBBERT \\ Department of Zoology, University of Western Australia Nedlands, Western Australia 6009 \\ Received (Re-submitted) 29.iii.84
}

\section{SUMMARY}

Sex-linkage of phosphoglucomutase (PGM) is widespread in the Orthoptera. For each of three species studied (representing the two suborders), the specific activity of PGM in males (the heterogametic sex) is almost identical to that in females, providing direct evidence that the difference in gene dose of a sex-linked locus in males and females is compensated in the Orthoptera. The Orthoptera is only the third group for which compensation has been demonstrated. Dosage compensation has been investigated in three orders of insects: it is present in Orthoptera and Diptera but absent in Lepidoptera. It is postulated that dosage compensation arose or was present in related archopteran ancestors and has been secondarily lost in Lepidoptera, possibly in association with female heterogamety in this group.

\section{INTRODUCTION}

In diploid, sexually reproducing organisms, the heterogametic sex, which carries a pair of heteromorphic sex chromosomes (XY or $\mathrm{ZW}$ ), has only half as many copies of each X-linked gene as the homogametic sex of the same species. Yet, in a number of cases, differences in the activities of $\mathrm{X}$-linked genes have been shown to be of selective importance and one would expect such an inequality in gene dose, if left uncompensated, to result in differential selection between the sexes.

In both mammals and Drosophila there is "compensation" for this difference in gene dose, so ensuring that males and females produce equal amounts of enzymes from such sex-linked genes. In mammals, dosage compensation is achieved by inactivation of one of the $\mathrm{X}$-chromosomes in the somatic cells of the female (the homogametic sex), so equalising the gene dose in males and females (Lyon, 1972). In Drosophila, an alternative mechanism of dosage compensation (dosage compensation sensu strictu) has evolved, whereby the effective dose of $\mathrm{X}$-linked genes is equalised in the two sexes by an increased rate of transcription in the male (Lucchesi, 1973).

Dosage compensation however, is not universal. In birds, the pattern of expression of a number of sex-linked mutant genes determining plumage phenotypes strongly suggests a lack of dosage compensation of the genes involved (Cock, 1964). More direct evidence is the absence of compensation

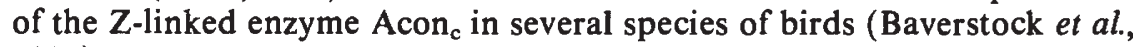
1982).

Direct evidence for the absence of dosage compensation of a sex-linked gene also exists in Lepidoptera (Johnson and Turner, 1979). In the two species of Heliconius butterflies studied, the specific activity of the Z-linked 
enzyme 6PGD in males (the homogametic sex) was found to be twice that in females. Indeed, additional indirect evidence for the absence of dosage compensation in Lymantria and Choristoneura (Goldschmidt, 1921; Stehr, 1959), suggests that the absence of dosage compensation in Lepidoptera may be a general phenomenon (Johnson and Turner, 1979).

As pointed out by Johnson and Turner (1979), there is some regularity in the occurrence of compensation. In both groups where dosage compensation is known (mammals and Drosophila) the male is the heterogametic sex whilst in those groups where dosage compensation is lacking (birds and Lepidoptera), female heterogamety occurs.

To date the scarcity of information on sex-linked enzymes has prevented the evaluation of the prevalence of dosage compensation in other groups of organisms. Recent electrophoretic studies on Mygalopsis marki (Tettigoniid-Orthoptera) indicate that the enzyme phosphoglucomutase (PGM, E.C.2.7.5.1) is sex-linked in this species (Dadour and Johnson, 1983). In this paper, I present the first evidence for dosage compensation of a sex-linked locus in the Orthoptera, which in keeping with the pattern of all other groups known to show dosage compensation (mammals and Drosophila) display male heterogamety.

\section{MAterials AND METHODS}

\section{(i) Orthopteran species studied}

In the present study, variation in PGM was assessed in a range of species from three families of the Orthoptera: Tettigoniidae and Gryllidae (Suborder Ensifera) and Acrididae (Suborder Caelifera). The Tettigoniidae were represented by Mygalopsis marki Bailey (Copiporinae); Pachysigella australis Walker (Saginae); Hemisaga denticulata White (Saginae); Requena verticalis Walker (Listroscelinae); Phasmodes ranatriformis Westwood (Phasmodinae), Conocephalus upoluensis Karny (Conocephalinae), Tympanophora similis Riek (Tympanophorinae), an unknown species of Metaballus (Tettigoniinae) and an unknown genus and species of Zaprochilinae whilst the Gryllidae and Acrididae were each represented by a single species, Teleogryllus oceanicus Le Guillou and Goniaea australasi respectively. In addition, several species of Blattodea and Hemiptera were screened for variability at the PGM locus.

\section{(ii) Laboratory crosses}

Indications of sex-linkage of PGM were tested by performing a series of laboratory crosses with adult $M$. marki of known genotype. The resultant progeny were raised under constant temperature conditions to 2 nd or 3 rd instar, sexed and their PGM genotype determined electrophoretically.

\section{(iii) Electrophoresis}

Homogenates were prepared by grinding muscle extracted from the femur and tibia of the metathoracic leg in a 10 per cent sucrose solution containing 0.1 per cent mercaptoethanol. The remainder of each specimen 
was frozen for possible later use in enzymatic analysis. Electrophoresis of the homogenates was performed on horizontal starch gel (Electrostarch) following the technique of Brewer (1970).

PGM was electrophoresed on tris-maleate buffer $(p \mathrm{H} \mathrm{7.4)}$. PGM is monomeric, with heterozygotes displaying two isozymes and homozygotes one. Alleles were labelled alphabetically, in order of decreasing electrophoretic mobility of their respective allozymes. The assay recipe was essentially that of Shaw and Prasad (1970).

\section{(iv) Enzyme activities}

Enzyme assays were performed on field-collected nymphs of $M$. marki ( $\mathrm{A}^{3}$ and $\mathrm{A}^{2}$ nymphs) and $G$. australasi ( $\mathrm{A}^{3}$ nymphs), and on adults of an unknown genus and species of Zaprochilinae. In each case, only one PGM locus was present and males and females homozygous for the same PGM variant were used to control for any differences in the enzyme activities of the different allozymes. Only the head, thorax and limbs were used in the preparation of extracts, 20 to $40 \mathrm{mg}$ of tissue (3 to 4 nymphs) being homogenised in $10 \mathrm{mM}$ tris- $10 \mathrm{mM}$ maleic acid-1 mM EDTA-1 mM $\mathrm{MgCl}_{2}$ $(p \mathrm{H} \mathrm{7.4)} \mathrm{(Buffer} \mathrm{A)} \mathrm{at} \mathrm{a} \mathrm{concentration} \mathrm{of} 0.2 \mathrm{~g}$ per ml. Homogenates were incubated for 15 minutes in an ice bath and then centrifuged at $3000 \mathrm{rpm}$ for 60 minutes at $4^{\circ} \mathrm{C}$ to remove debris. The resultant supernatant was centrifuged for a further 5 minutes to remove any remaining suspended material so ensuring a relatively clear crude extract was obtained. For $M$. marki ten preparations from males and nine preparations from females were made. For $G$. australasi, five extracts from males and six from females were made while for the species of Zaprochilinae six extracts each from males and females were made.

PGM activity was measured by a coupled assay, similar to the spectrophometric assay of Joshi et al., (1967) (Fucci et al., 1979). The assay medium contained $50 \mathrm{mM}$ tris, $50 \mathrm{mM}$ maleic acid at $p \mathrm{H} \mathrm{7 \cdot 4,4} \mathrm{mM}$ glucose1-phosphate (containing 1 per cent glucose-1,6-diphosphate), $200 \mu \mathrm{M} N A D$, $1 \mathrm{mM}$ EDTA, $5 \mathrm{mM} \mathrm{MgCl}$ and 0.6 enzyme unit of glucose-6-phosphate dehydrogenase in a total volume of $3 \mathrm{ml}$. For each species, the volume of extract added to the assay medium was determined from the enzyme dilution curve characteristic of that species, so ensuring that the observed activity was a function of the extract concentration (and hence PGM concentration) and not limited by other factors. All substrates and cofactors were obtained from Sigma Chemical Co. (Saint Louis, Missouri).

Reaction mixtures, excluding the substrate, were incubated for 15 minutes at $25^{\circ} \mathrm{C}$ and transferred to a $1 \mathrm{~cm}$ pathlength quartz cuvette immediately following the addition of substrate. The reaction was followed as an increase in absorbance at $340 \mathrm{~nm}$ using a UV-Visible light spectrophotometer (Beckman model 26). Reaction rates were measured at $25^{\circ} \mathrm{C}$ for 6 minutes, the rate being linear during this period. The reference cuvette contained the assay mixture, excluding the substrate. Each sample was assayed three to four times and the mean enzyme activity was used as a measure of the enzyme activity for that sample. Protein concentrations of the extracts were determined by ultraviolet absorbance (Layne, 1963) and the specific enzyme activities were expressed as $\mu$ moles $\mathrm{NADH}$ converted per min. per mg. protein (Bergmeyer, 1963). 


\section{RESUltS}

\section{(i) Sex-linkage of PGM}

PGM is X-linked in $M$. marki, as indicated by the complete absence of heterozygous males (the heterogametic sex) in the laboratory crosses (table 1). A total of ten progeny, four females and six males were obtained from two identical crosses (cross 1 and 2: $\mathrm{PGM}^{\mathrm{a}} / \mathrm{PGM}^{\mathrm{a}} \times \mathrm{PGM}^{\mathrm{b}}$ ). All of the four daughters were heterozygous $\left(\mathrm{PGM}^{\mathrm{a}} / \mathrm{PGM}^{\mathrm{b}}\right.$ ) confirming that fertilisation had occurred, whilst the sons were all hemizygous for the maternal genotype $\left(\mathrm{PGM}^{\mathrm{a}}\right)$, demonstrating that PGM is sex-linked in this species. Such PGM ${ }^{\mathrm{a}}$ sons are impossible (barring mutation) in the crosses made, if the gene coding for PGM is autosomally inherited.

No heterozygous males have been found in any species of Tettigoniid (Suborder Ensifera) examined (table 2), suggesting that PGM is typically

\section{TABLE 1}

Comparison of PGM phenotypes of male and female progeny from laboratory crosses of Mygalopsis marki

\begin{tabular}{clll}
\hline & \multicolumn{3}{c}{ Progeny } \\
\cline { 2 - 4 } $\begin{array}{c}\text { PGM phenotypes } \\
\text { of parents } \\
\text { o } \delta\end{array}$ & Sex & \multicolumn{2}{c}{ PGM phenotypes } \\
\cline { 2 - 4 } & Male & 5 & $a b$ \\
\hline $1 . a \times b$ & Fernale & 0 & 1 \\
$2 . a \times b$ & Male & 1 & 0 \\
& Fernale & 0 & 3 \\
\hline
\end{tabular}

TABLE 2

Comparison of homozygotes and heterozygotes for PGM in males and females of a range of orthopteran species and for species of Blattodea and Hemiptera

\begin{tabular}{|c|c|c|c|c|c|}
\hline \multirow[b]{2}{*}{ Species } & \multicolumn{2}{|c|}{ Females } & \multicolumn{2}{|c|}{ Males } & \multirow{2}{*}{$\begin{array}{c}\text { Fisher's } \\
\text { Exact } \\
\text { p }\end{array}$} \\
\hline & Homozygotes & Heterozygotes & Homozygotes & Heterozygotes & \\
\hline \multirow{2}{*}{\multicolumn{6}{|c|}{$\begin{array}{l}\text { O. Orthoptera } \\
\text { S. O. Ensifera }\end{array}$}} \\
\hline & & & & & \\
\hline \multicolumn{6}{|l|}{ F. Tettigoniidae } \\
\hline R. verticalis & 10 & 3 & 21 & 0 & 0.0478 \\
\hline T. similis & 19 & 9 & 36 & 0 & 0.0002 \\
\hline P. australis & 6 & 7 & 7 & 0 & 0.0221 \\
\hline H. denticulata & 3 & 1 & 2 & 0 & - \\
\hline P. ranatriformis & 2 & 2 & 11 & 0 & 0.0571 \\
\hline Zaprochiline sp. & 41 & 20 & 40 & 0 & 0.0000 \\
\hline \multirow{2}{*}{\multicolumn{6}{|c|}{$\begin{array}{l}\text { S. O. Caelifera } \\
\text { F. Acrididae }\end{array}$}} \\
\hline & & & & & \\
\hline G. australasi & 23 & 43 & 67 & 0 & 0.0000 \\
\hline \multicolumn{6}{|l|}{ O. Blattodea } \\
\hline F. Blattidea & 14 & 0 & 15 & 0 & \\
\hline \multicolumn{6}{|l|}{ O. Hemiptera } \\
\hline S. O. Heteroptera & 4 & 3 & 7 & 3 & 0.3394 \\
\hline
\end{tabular}


sex-linked in this group. In addition, the observed genotypic frequencies of the acridid G. australasi (Suborder Caelifera) are consistent with the locus coding for PGM being on the X-chromosome. The complete absence of heterozygous males, contrasted with the relative commonness of heterozygous females, in all species of Orthoptera studied suggests that X-linkage of PGM is widespread throughout the Orthoptera.

The possibility of X-linkage of PGM was investigated in species of Blattodea and Hemiptera, both of which share a group of related ancestors with the Orthoptera. PGM was found to be homozygous for the same isozyme in both species of Blattidae (Order Blattodea) examined, precluding any information on X-linkage of PGM in this group. In the heteropteran species (Order Hemiptera), heterozygotes of each sex were found for PGM (table 3), indicating that PGM is autosomal in this species.

TABLE 3

Means ( \pm S.E.) and analysis of variance of PGM specific activities in nymphal males and females of M. marki. Specific activities expressed as $\mu$ moles $N A D H \times 10^{2}$ converted per min per mg protein

\begin{tabular}{|c|c|c|c|c|c|}
\hline \multicolumn{6}{|c|}{ Mygalopsis marki } \\
\hline \multicolumn{2}{|c|}{$\begin{array}{c}2 \cdot 247 \pm 0 \cdot 58 \\
n=10\end{array}$} & \multicolumn{4}{|c|}{$\begin{array}{c}2 \cdot 191 \pm 0 \cdot 36 \\
n=9\end{array}$} \\
\hline Source of variation & d.f. & S.S. & M.S. & $F$ & $P$ \\
\hline $\begin{array}{l}\text { Sex (S) } \\
\text { Nymphal Stage (N) } \\
\mathrm{S} \times \mathbf{N} \\
\text { Residual }\end{array}$ & $\begin{array}{r}1 \\
1 \\
1 \\
15\end{array}$ & $\begin{array}{r}0 \cdot 151 \\
6 \cdot 734 \\
4 \cdot 094 \\
27 \cdot 913\end{array}$ & $\begin{array}{l}0 \cdot 151 \\
6 \cdot 734 \\
4 \cdot 094 \\
1.861\end{array}$ & $\begin{array}{l}0 \cdot 081 \\
3 \cdot 619 \\
2 \cdot 200\end{array}$ & $\begin{array}{l}\text { N.S. } \\
\text { N.S. } \\
\text { N.S. }\end{array}$ \\
\hline
\end{tabular}

(ii) Dosage compensation

No significant difference in PGM activity was apparent between $\mathrm{A}^{3}$ and $\mathrm{A}^{2}$ nymphal stages of $M$. marki (table 3 ) allowing the data to be pooled for comparisons between the sexes. The specific activity of PGM in males is almost identical to that in females (table 3 ): the ratio of activity in males to activity in females is very close to 1.00 (male: female $=1.025$ ), indicating phenotypic equivalency between the two sexes despite differences in gene dose. This clearly indicates that the difference in gene dose of the sex-linked enzyme, PGM, is compensated for in $M$. marki.

TABLE 4

Comparison of specific activities of PGM in males and females of Zaprochiline sp. (S. O. Ensifera) and $\mathrm{G}$. australasi (S. O. Caelifera). Values are mean \pm S.E. $\mu$ moles $N A D H \times 10^{2}$ converted per min per $\mathrm{mg}$ protein

\begin{tabular}{lcccrc}
\hline \multicolumn{1}{c}{ Species } & Males & Females & $t$ & d.f. & $p$ \\
\hline Zaprochiline sp. & $0.945 \pm 0.11$ & $0.848 \pm 0.10$ & 0.687 & 10 & N.S. \\
G. australasi & $3.344 \pm 0.22$ & $4 \cdot 115 \pm 0.36$ & 1.711 & 9 & N.S. \\
\hline
\end{tabular}


No differences in PGM activity between male and female Zaprochilinae, a second species of Tettigoniidae, were found, indicating that the X-linked gene coding for PGM is also subject to dosage compensation in this species (table 4). To determine the extent of dosage compensation within the order Orthoptera, PGM activities in the acridid G. australasi (Suborder Caelifera) were determined. As in ensiferan species, PGM activity was found to be similar in males and females (table 4), suggesting that dosage compensation of PGM is widespread throughout the Orthoptera.

\section{Discussion}

PGM is an important intermediary enzyme which catalyses the reaction which links the pathways of gluconeogenisis and glycolysis. Indeed, genetic variation in PGM activity has been shown to be of adaptive significance in a number of species, with different allozyme variants being selectively favoured under different environmental conditions (Bullini and Colluzi, 1972; Markinovic and Ayala, 1975; Leigh Brown, 1977; Steiner, 1979; Fucci et al., 1979). Consequently, in the Orthoptera, where the gene coding for PGM is sex-linked, one would predict strong selection for dosage compensation, so preventing differential selection between the sexes.

The present data demonstrate that PGM is subject to dosage compensation in the three orthopteran species studied: $M$. marki, G. australasi and an unknown Zaprochiline species. In these species males and females are phenotypicaliy identical with respect to PGM activity (the activity ratio of males:females being close to 1.00 ) providing direct evidence that the difference in gene dose of X-linked PGM in males and females has been compensated for. While it could be that the male has exactly twice the amount of all gene products as the female, this seems highly unlikely in view of the fact that in all three species studied, males had almost identical PGM activity to females.

The presence of dosage compensation in species of both the Caeliferan and the more primitive Ensiferan suborders, suggests that dosage compensation of the X-linked gene coding for PGM was present in ancestral orthopterans, and has been conserved throughout the Orthoptera. However, the question of whether dosage compensation is a general phenomenon in this order, or is restricted to a few compensated loci, still remains to be answered. One would expect dosage compensation of most sex-linked genes to have evolved so preventing differential selection between the sexes. Nevertheless, dosage compensation of individual genes or small portions of the chromosomes has been shown in Drosophila (Bowman and Simmons, 1973; Lucchesi, 1973) and whether a gene is compensated appears to be dependent on the evolutionary recency of its location on the X chromosome (Strobel et al., 1978). The observed dosage compensation of the gene coding for PGM in the Orthoptera confirms expectations based on its important intermediary role in carbohydrate metabolism and its longstanding history of $\mathrm{X}$-linkage in this group. In order to determine if dosage compensation is in fact a general phenomenon it is necessary to examine a variety of enzymes where dosage compensation would not necessarily be expected.

The Orthoptera is only the third group of animals shown to have dosage compensation and following the pattern of other groups where dosage compensation is known (mammals and Drosophila), the male is the 
heterogametic sex. This consistent relationship between male heterogamety and the presence of dosage compensation strengthens the belief that the absence or loss of dosage compensation evident in birds and lepidopterans is associated with female heterogamety. The underlying reason(s) for such an association between the presence or absence of dosage compensation and the sex-determining mechanism, however, remain to be determined.

\section{(i) Evolution of dosage compensation}

The finding that X-linked gene(s) are dosage compensated in the Orthoptera, as in Drosophila (Diptera), together with its absence in Lepidoptera, enables speculation as to the evolutionary origins of dosage compensation in these neopteran groups. Are the presence or absence of dosage compensation in these groups evolutionarily independent events?

It is generally accepted that there were three main lines of neopterous evolution: the blattoid-orthopteroid, hemipteroid and panorpoid or endopterygote (including Diptera and Lepidoptera) lines, which probably arose independently from a group of archopteran ancestors (Sharov, 1971). Therefore, the most parsimonious hypothesis for the evolution of dosage compensation in these groups is that dosage compensation arose or was present in related archopteran ancestors and has been secondarily lost in Lepidoptera (fig. 1), possibly in association with the presence of female heterogamety

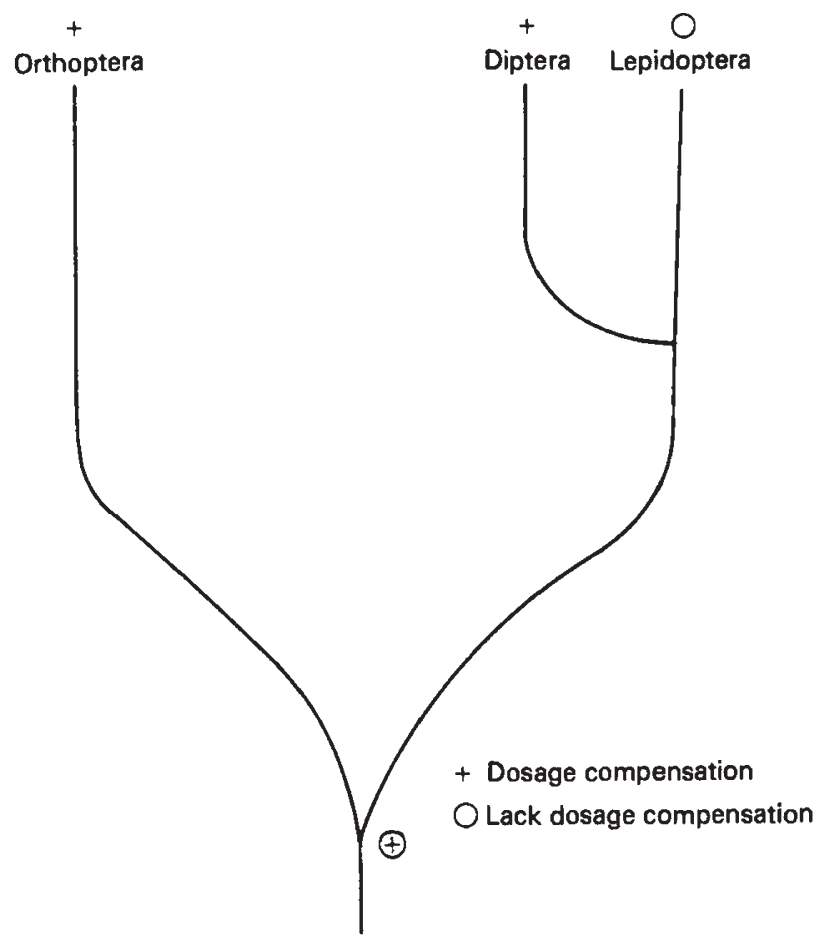

FIG. 1. Diagrammatic Representation of the Phylogenetic Relationships between the Orthoptera, Diptera and Lepidoptera showing the presence or absence of dosage compensation in these groups together with the proposed presence of dosage compensation in the ancestral group. 
in this group. Moreover, the evolution of female heterogamety in the trichopteran-lepidopteran line and proposed associated loss of dosage compensation, at least in Lepidoptera, is a relatively recent evolutionary event (Permian-Recent) (Riek, 1970) when compared with male heterogamety, and presumably dosage compensation, which is inferred to have occurred in the Carboniferous neopteran ancestors, adding credibility to this hypothesis.

The implication that the lack of dosage compensation is the derived rather than ancestral character associated with the presence of female heterogamety may be tested, although the insects may not be the group in which to do it. The Trichoptera and Lepidoptera, both of which display female heterogamety, are universally regarded as closely allied orders (White, 1945) and although the determination of dosage compensation in these Trichoptera would be of interest, it would not provide an independent test of this implied association. Rather an investigation into the occurrence of dosage compensation and associated modes of sex-determination in reptiles, from which both mammals and birds descended, would provide an independent test of whether in fact the absence of dosage compensation is derived in groups where female heterogamety occurs.

Acknowledgements. I would like to thank Dr M. S. Johnson for assistance throughout this study and valuable criticism of the manuscript. Dr W. J. Bailey, Mr D. Gwynne, Mr A. Lymbery, Mr I. R. Dadour and Mr I. McCauley provided assistance and helpful discussions during the course of this study. This study formed a portion of a B.Sc Honours degree completed by D.R.H., and was supported financially by the Department of Zoology, University of Western Australia.

N.B. Voucher specimens of all species used in the present study are lodged in the insect collection of the University of Western Australia.

\section{RefERENCES}

BAVERSTOCK, P. R., ADAMS, M., POLKINGHORNE, R. W. AND GELDER, M. 1982. A sex-linked enzyme in birds-Z-chromosome conservation but no dosage compensation. Nature, 296, 763-767.

BERGMEYER, H. U. 1963. Methods of Enzymatic Analysis Vol. 1. 2nd Ed. Academic Press, New York, 499-500.

BOWMAN, J. T. AND sIMmons, J. R. 1973. Gene modulation in Drosophila: Dosage compensation of $\mathrm{Pgd}^{+}$and $\mathrm{Zw}^{+}$genes. Biochemical Genetics., 10, 319-331.

BREWER, G. J. 1970. An Introduction to Isozyme Techniques. Academic Press, New York.

BULLINI, L. AND COLLUZZI, M. 1972. Natural selection and genetic drift in protein polymorphism. Nature, 239, 160-161.

COCK, A. G. 1964. Dosage compensation and sex-chromatin in non-mammals. Genetical Research, 5, 354-365.

DADOUR, I. R. AND JOHNSON, M. S. 1983. Genetic differentiation, hybridization and reproductive isolation in Mygalopsis marki (Orthoptera: Tettigoniidae). Australian Journal of Zoology, 31(3).

FuCCI, L., GAUDIO, L., RAO, R., SPANò, A. AND CARfagna, M. 1979. Properties of the two common electrophoretic variants of phosphoglucomutase in D. melanogaster. Biochemical Genetics, 17, 825-836.

GOLDSCHMIDT, R. B. 1921. Erblichskeitstudien an Schmetterlingen III. Der Melanismus der Noune, Lymantria monacha L. Zeitschrift für induktive Abstammungs-und Vererbungslehre, 25, 89-163.

JOHNSON, M. S. AND TURNER, J. R. 1979. Absence of dosage compensation for a sex-linked enzyme in butterflies (Heliconius). Heredity, 43(1), 71-77. 
JOSHI, J. G., HOOPER, J., KUWAKI, T., SAKURADA, T., SWANSON, J. R. AND HANDLER, P. 1967. Phosphoglucomutase, V. Multiple forms of phosphoglucomutase. Proceedings of the National Academy of Science, 57, 1482-1489.

LAYNE, E. 1963. Spectrophotometric and turbidimetric methods for measuring proteins. Methods in Enzymology, III, 448-454.

LEIGH BROWN, A. J. 1977. Physiological correlates of an enzyme polymorphism. Nature, 269, 803-804.

LUCCHESI, J. C. 1973. Dosage compensation in Drosophila. Annual Review of Genetics, 7, 225-237.

LYON, M. F. 1972. X-chromosome inactivation and developmental patterns in mammals. Biological Reviews, 47, 1-35.

MARKINOVIC, D. AND AYALA, F. J. 1975. Fittness of allozyme variants in Drosophila pseudoobscura. I. Selection at the PGM-1 and Me-2 loci. Genetics, 79, 85-95.

RIEK, E. F. 1970. Fossil history. In The Insects of Australia Melbourne University Press, Victoria.

SHAROV, A. G. 1971. Phylogeny of the Orthopteroidea. c. Academy of Sciences of the U.S.S.R. Vol. 118. B. B. Rodendorf (ed.) Keter Press, Jerusalem.

SHAW, C. R. AND PRASAD, R. 1970. Starch gel electrophoresis of enzymes. A compilation of recipes. Biochemical Genetics, 4, 297-320.

STEHR, G. 1959. Haemolymph polymorphism in a moth and the nature of sex-controlled inheritance. Evolution, 13, 537-560.

STEINER, W. M. 1979. Genetic variation in Hawaiian Drosophila. VIII. Heterozygosity and genetic changes in isolated populations of D. Engyochracea. Biochemical Genetics, 17, $645-661$.

STROBEL, E., PELling, C. AND ARNHEIM, N. 1978. Incomplete dosage compensation in an evolving Drosophila sex chromosome. Proceedings of the National Academy of Sciences, U.S.A., 76, 1924-1928.

WHITE, M. J. D. 1945. Animal Cytology and Evolution. University Press, Cambridge.

WHITE, M. J. D. 1970. Cytogenetics. In The Insects of Australia. Melbourne University Press, Victoria. 